\title{
Skeptisme Profesional Memoderasi Pengaruh Audit Training Pada Kemampuan Deteksi Kecurangan
}

\author{
Cok Istri Mirah Pradnya Ningrat Pemayun ${ }^{1}$ \\ A.A.N.B. Dwirandra ${ }^{2}$ \\ ${ }^{1,2}$ Fakultas Ekonomi dan Bisnis Universitas Udayana (Unud), Bali, Indonesia \\ e-mail: cokistrimirah@yahoo.com
}

\begin{abstract}
ABSTRAK
Tujuan penelitian ini untuk mendapatkan bukti empiris pengaruh positif audit training pada kemampuan deteksi kecurangan, serta skeptisme profesional memperkuat pengaruh positif audit training pada kemampuan deteksi kecurangan. Penelitian ini dilakukan di Kantor Akuntan Publik Provinsi Bali yang terdaftar di Institut Akuntan Publik Indonesia. Populasi penelitian ini adalah seluruh auditor yang bekerja pada KAP di Provinsi Bali. Sampel ditentukan menggunakan metode purposive sampling. Metode pengumpulan data dilakukan dengan menggunakan metode kuesioner dan teknik analisis data yang digunakan adalah analisis linier berganda dan moderated regression analysis. Berdasarkan analisis ditemukan bahwa audit training berpengaruh positif pada kemampuan deteksi kecurangn, dan skeptisme profesional mampu menguatkan pengaruh audit training pada kemampuan deteksi kecurangan.
\end{abstract}

Kata kunci: Kemampuan deteksi kecurangan, audit training, dan skeptisme professional

\begin{abstract}
The purpose of this study is to obtain empirical evidence of the positive influence of training audits on fraud detection capabilities, and professional skepticism to strengthen the positive influence of training audits on fraud detection capabilities. This research was conducted at the Bali Provincial Public Accountants Office registered with the Indonesian Institute of Certified Public Accountants. The population of this research is all auditors who work in KAP in Bali Province. The sample is determined using the purposive sampling method. The method of data collection is done using the questionnaire method and the data analysis techniques used are multiple linear analysis and moderated regression analysis. Based on the analysis it was found that audit training had a positive effect on lack of detection ability, and professional skepticism was able to strengthen the effect of audit training on fraud detection capabilities.
\end{abstract}

Keywords: Fraud detection capabilities, audit training, and professional skepticism

\section{PENDAHULUAN}

Berdasarkan Standar Audit (SA) 240 tentang Tanggung Jawab Auditor Terkait Dengan Kecurangan Dalam Suatu Audit Atas Laporan Keuangan, menyatakan bahwa "Auditor melaksanakan audit berdasarkan SA bertanggung jawab untuk memperoleh keyakinan memadai apakah laporan keuangan secara keseluruhan bebas dari kesalahan penyajian material, yang disebabkan oleh kecurangan atau 
kesalahan.” Berdasarkan standar auditing tersebut profesi auditor dipercaya untuk melakukan audit atas laporan keuangan yang disajikan manajemen untuk memberikan pendapat/opini terkait kewajaran dan atau ada tidak adanya salah saji material dalam laporan keuangan.

Akan tetapi, masih terdapat kasus-kasus mengenai kecurangan akuntansi yang menunjukkan masih terjadinya kegagalan dalam dunia audit. Kecurangan atau fraud merupakan suatu istilah umum yang mencakup penggunaan segala macam cara dengan keahlian tertentu, yang dipilih oleh individu guna mendapatkan keuntungan dari pihak lain dengan melakukan representasi yang salah (Tunggal, 2016). Sehingga dapat dikatakan bahwa fraud sebagai suatu tindakan penipuan yang sengaja dilakukan sehingga menimbulkan kerugian bagi pihak lain dan memberikan keuntungan bagi pelaku kecurangan tersebut.

Tidak sedikit perusahaan yang terdaftar di pasar modal tersangkut masalah hukum yang dimana perusahaan tersebut telah diaudit dan bahkan beberapa di antaranya memperoleh opini wajar tanpa pengecualian/WTP. Menurut Maulana (2014) salah satu kasus yang ramai diberitakan adalah keterlibatan 10 KAP di Indonesia dalam praktik kecurangan Keuangan. KAP-KAP tersebut ditunjuk untuk mengaudit 37 bank sebelum terjadinya krisis keuangan pada tahun 1997. Hasil audit mengungkapkan bahwa laporan Keuangan bank-bank tersebut sehat. Ternyata, ketikakrisis menerpa Indonesia, bank-bank tersebut kolaps karena kinerja keuangannya sangat buruk. Hal ini terungkap dalam investigasi yang dilakukan pemerintah bahwa KAP-KAP tersebut terlibat dalam praktik kecurangan akuntansi. 
Selain terlibatnya 10 KAP di Indonesia tersebut, banyak kasus di Indonesia juga yang melibatkan auditor independen yang gagal mendeteksi kecurangan maupun auditor tidak independen. Kasus yang pernah terjadi adalah kasus PT Kimia Farma (2001) dimana manajemen Kimia Farma melaporkan adanya laba bersih sebesar Rp 132 milyar, dan laporan tersebut di audit oleh Hans Tuanakotta \& Mustofa (HTM) sedangkan Kementerian BUMN dan Bapepam menyajikan kembali laporan keuangan tersebut dan dihasilkan keuntungan yang disajikan hanya sebesar Rp 99, 56 miliar, atau lebih rendah sebesar Rp 32,6 milyar, atau $24,7 \%$ dari laba awal yang dilaporkan. HTM dinyatakan tidak mampu mendeteksi laporan keuangan tersebut apakah mengandung unsur kecurangan atau tidak (Wiguna, 2015). Kasus lain yang juga telah terjadi di Indonesia adalah kasus pada PT. Telkom, dimana laporan keuangan PT. Telkom yang telah diaudit oleh KAP Eddy Pianto dan Rekan tidak diakui oleh Securities and Exchange Commission sehingga pihak PT. Telkom diminta kembali untuk melakukan audit atas laporan keuangannya (Nasution, 2013).

Berdasarkan hasil wawancara dengan beberapa auditor yang terdapat pada salah satu kantor akuntan publik di Provinsi Bali, diinformasikan bahwa auditor di KAP tersebut pernah menemukan adanya kecurangan yang dilakukan oleh manajemen perusahaan. Kecurangan yang sering terjadi biasanya ditemukan pada kas, dan persedian yang tidak sesuai dengan fisiknya. Kecurangan-kecurangan tersebut pernah ditemukan oleh auditor yang terdapat di salah satu KAP Provinsi Bali. Berdasarkan hal tersebut, maka kemampuan auditor dalam mendeteksi kecurangan perlu untuk ditingkatkan. 
Cok Istri Mirah Pradnyaningrat Pemayun dan A.A.N.B. Dwirandra. Skeptisme...

Realitas adanya fenomena kecurangan yang dilakukan oleh manajemen perusahaan publik mengindikasikan masih lemahnya kemampuan deteksi kecurangan auditor KAP dan sudah tentu tidak sesuai dengan yang ditegaskan Institut Akuntan Publik Indonesia (IAPI) dalam Standar Profesional Akuntan Publik (SPAP) tentang Tanggung Jawab Auditor untuk pencegahan dan pendeteksian kecurangan ayat 4 dan 5, yang menegaskan sebagai berikut:

Ayat 4: "Tanggung jawab utama untuk pencegahan dan pendeteksian kecurangan berada pada dua pihak yaitu yang bertanggung jawab atas tata kelola entitas dan manajemen. Merupakan hal penting bahwa manajemen, dengan pengawasan oleh pihak yang bertanggung jawab atas tata kelola, menekankan pencegahan kecurangan, yang dapat mengurangi peluang terjadinya kecurangan, dan pencegahan kecurangan (fraud deterrence), yang dapat membujuk individuindividu agar tidak melakkan kecurangan karena kemungkinan akan terdeteksi dan terkena hukuman..."

Ayat 5: "Auditor yang melaksanakan audit berdasarkan SA bertanggung jawab untuk memperoleh keyakinan memadai apakah laporan keuanggan secara keseluruhan bebas dari salah penyajian material, yang disebabkan oleh kecurangan atau kesalahan...”

Standar tersebut mengindikasikan bahwa auditor perlu untuk lebih mampu dalam melakukan pencegahan ataupun pendeteksian adanya kecurangan pada perusahaan yang di audit.

Terdapat berbagai faktor yang diperkirakan menjadi penyebab auditor tidak mampu mendeteksi kecurangan yaitu faktor yang berasal dari diri auditor 
(sisi internal) dan faktor yang berasal bukan dari diri auditor (sisi eksternal). Faktor internal yang dimaksud meliputi kepribadian auditor, etika auditor, dan sikap skeptisme yang dimiliki auditor. Sedangkan faktor eksternal meliputi tugas audit, dan pelatihan audit (Pambudi, 2016). Sehingga, kurangnya pelatihan yang diikuti oleh seorang auditor bisa menjadi salah satu faktor yang menyebabkan menurunnya kemampuan auditor dalam mendeteksi kecurangan (Pramudyastuti, 2014). Menurut Ulfa (2015), seorang auditor yang memiliki pelatihan yang lebih sering cenderung akan lebih mampu dalam mendeteksi kecurangan. Pelatihan akan menambah pengetahuan auditor mengenai lingkungan kerjanya, auditor lebih peka terhadap red flags kecurangan, sehingga auditor lebih mampu untuk mendeteksi kecurangan.

Haryanti (2013) menyatakan bahwa dengan adanya pelatihan mungkin menyebabkan struktur pengetahuan auditor tentang kekeliruan akan bertambah. Melalui pendidikan, pelatihan, dan pengalaman auditor akan menjadi ahli di bidang akuntansi dan pengauditan, serta memiliki kemampuan untuk menilai dan mempertimbangkan secara objektif dan tidak memihak terhadap informasi dalam pembukuan perusahan atau informasi lain yang berhasil diungkapkan melalui auditnya.

Akuntan publik juga harus menjalani pelatihan teknis yang cukup mencakup aspek teknis maupun pendidikan umum. Pelatihan yang dimaksud dapat berupa kegiatan-kegiatan, seperti: seminar, simposium, lokakarya, pelatihan itu sendiri, dan kegiatan penunjang keterampilan lainnya. Oleh sebab itu, 
Cok Istri Mirah Pradnyaningrat Pemayun dan A.A.N.B. Dwirandra. Skeptisme...

pelatihan dapat meningkatkan kemampuan kerja auditor dalam mendeteksi kecurangan (Bulchia, 2008).

Meski dikatakan bahwa audit training mampu meningkatkan kompetensi auditor dalam mengungkapkan kecurangan laporan keuangan, namun masih saja terdapat perusahaan-perusahaan yang setelah mendapatkan pengakuan WTP (wajar tanpa pengecualian) terjebak sebuah kasus yang membuktikan adanya kecurangan seperti fenomena-fenomena yang terjadi (Pramudyastuti, 2014). Kemungkinan terdapat faktor lain yang menyebabkan hal tersebut terjadi.Kemungkinan belum adanya kesatuan hasil penelitian yang tergantung faktor-faktor tertentu atau lebih dikenal dengan istilah faktor kontinjensi. Agar dapat merekonsiliasi hasil yang saling bertentangan diperlukan pendekatan kontinjensi untuk mengindentifikasi variabel lain yang bertindak sebagai pemoderasi ataupun pemediasi dalam model riset.

Berdasarkan hasil riset yang dilakukan oleh Ulfa (2015), pelatihan memiliki hubungan yang positif dan signifikan terhadap kemampuan mendeteksi kecurangan. Hal ini menunjukan bahwa seorang auditor yang lebih sering mengikuti pelatihan maka cenderung akan lebih mampu mendeteksi kecurangan. Pelatihan akan menambah pengetahuan auditor mengenai lingkungan kerjanya, auditor lebih peka terhadap red flags kecurangan, sehingga auditor lebih mampu untuk mendeteksi kecurangan. Hasil yang sama pula disampaikan oleh Dandi (2017) yaitu pelatihan memiliki pengaruh yang signifikan terhadap kemampuan auditor dalam mendeteksi kecurangan. Sedangkan menurut hasil yang dilakukan oleh Hilmi (2011), pelatihan tidak berpengaruh secara signifikan terhadap 
kemampuan mendeteksi kecurangan. Begitu juga dengan hasil risetyang dilakukan oleh Sanjaya (2018) menunjukan hasil bahwa pelatihan tidak memiliki pengaruh terhadap tanggung jawab auditor auditor dalam mendeteksi kecurangan.

Berdasarkan uraian riset empiris tentang pengaruh audit training pada kemampuan deteksi kecurangan menunjukkan hasil yang tidak konsisten atau masih kontroversi, sehingga perlu diduga adanya faktor lain yang mempengaruhi variabel bebas dengan variabel terikatnya. Govindarajan (1986) menyatakan bahwa kemungkinan belum adanya kesatuan hasil penelitian tergantung faktor-faktor tertentu atau lebih dikenal dengan istilah faktor kontinjensi. Murray (1990) menjelaskan bahwa agar dapat merekonsiliasi hasil yang saling bertentangan diperlukan pendekatan kontinjensi untuk mengindentifikasi variabel lain yang bertindak sebagai pemoderasi ataupun pemediasi dalam model riset.

Secara konseptual dan hasil riset empiris maka dapat dikatakan bahwa terdapat variabel lain yang diduga mampu memoderasi pengaruh audit training pada kemampuan deteksi kecurangan, yaitu skeptisme profesional. Skeptisme professional dipilih menjadi variabel yang diduga mampu mempengaruhi hubungan audit training pada kemampuan deteksi kecurangan dikarenakan pelaku kecurangan akan selalu berusaha untuk menyembunyikan kecurangannya, sehingga diperlukan sikap skeptis auditoruntuk mendeteksi kecurangan (Ulfa, 2015). Noviyanti (2008) juga menyatakan bahwa tanpa menerapkan skeptisme professional, auditor hanya menemukan salah saji yang disebabkan oleh kekeliruan saja dan sulit untuk menemukan salah saji yang disebabkan oleh 
kecurangan. Selain itu berdasarkan studi empiris yang dilakukan oleh Anggriawan (2014), skeptisme professional berpengaruh positif terhadap kemampuan auditor dalam mendeteksi kecurangan. Hasil riset yang sama yang dilakukan oleh Putri, Wirama, dan Sudana (2017) serta Hilmi (2011) menunjukan bahwa skeptisme professional auditor berpengaruh secara signifikan terhadap kemampuan auditor dalam mendeteksi kecurangan. Oleh sebab itu, dapat diduga bahwa skeptisme professional mampu menguatkan hubungan audit training pada kemampuan deteksi kecurangan.

Fajarwati (2014) menyatakan bahwa skeptisme profesional auditor merupakan sikap yang dimiliki auditor yang selalu mempertanyakan dan meragukan bukti audit hal tersebut dapat diartikan bahwa skeptisme profesional menjadi salah satu faktor dalam menentukan kemahiran profesional seorang auditor. Skeptisme profesional auditor juga dapat dikatakan sebagai sebuah sikap yang menyeimbangkan antara sikap curiga dan sikap percaya. Keseimbangan sikap antara percaya dan curiga ini tergambarkan dalam perencanaan audit dengan prosedur audit yang dilakukan oleh akuntan publik. Pramudyastusi (2014) menyebutkan bahwa salah satu penyebab ketidakmampuan auditor dalam mendeteksi kecurangan dalam laporan keuangan itu adalah minimnya sikap skeptis yang dimiliki oleh auditor. Hal ini didukung dengan penelitian Noviyanti (2008) yang menyatakan bahwa kurangnya skeptisme profesional yang dimiliki oleh seorang auditor menyebabkan turunnya kemampuan auditor dalam mendeteksi kecurangan yang mungkin terjadi. Hal ini juga didukung oleh Public Company Accounting Oversight Board (2002) juga menemukan bahwa skeptisme 
profesional merupakan masalah yang serius pada auditor saat melakukan investigasi kecurangan, terutama dalam merespon risiko kecurangan sehingga gagal untuk memenuhi standar. Berdasarkan uraian di atas dapat dikatakan bahwa skeptisme profesional yang kuat membantu auditor meningkatkan kemampuan deteksi kecurangan, dan karenanya sangat patut diduga memiliki kemampuan dalam memoderasi audit training pada kemampuan auditor mendeteksi kecurangan.

Teori atribusi mengacu kepada penyebab suatu kejadian atau hasil yang diperoleh berdasarkan persepsi individu. Dalam penelitian ini teori atribusi menjelaskan pengaruh audit training terhadap auditor dalam melaksankan tugasnya dan tanggung jawabnya dalam mendeteksi suatu kecurangan yang mungkin terjadi. Auditor harus dapat merumuskan pendapatnya dengan baik dan mampu mendeteksi kecurangan yang mungkin terjadi (Wahyudi, Nur, \& Saidi, 2014). Apabila telah mengikuti audit training mungkin menyebabkan struktur pengetahuan auditor tentang kekeliruan akan bertambah. Melalui pendidikan, pelatihan dan pengalaman auditor akan menjadi ahli di bidang akuntansi dan pengauditan, serta memiliki kemampuan untuk menilai dan mempertimbangkan secara objektif dan tidak memihak terhadap informasi dalam pembukuan perusahan atau informasi lain yang berhasil diungkapkan melalui auditnya (Haryanti, 2013).

Teori disonansi kognitif (cognitive dissonance) dikembangkan oleh Leon Festinger pada tahun 1957. Teori ini mengatakan bahwa manusia pada dasarnya menyukai konsistensi, oleh karena itu manusia akan cenderung mengambil sikap 
yang tidak bertentangan satu sama lain dan menghindari melakukan tindakan yang tidak sesuai dengan sikapnya. Disonansi artinya adanya suatu inkonsistensi. Disonansi kognitif mempunyai arti keadaan psikologis yang tidak menyenangkan yang timbul ketika dalam diri manusia terjadi konflik antara dua kognisi atau konflik antara perilaku dan sikap. Dalam teori ini yang dimaksud dengan unsur kognitif adalah setiap pengetahuan, opini, atau apa yang dipercaya orang mengenai sesuatu obyek, lingkungan, diri sendiri atau perilakunya. Disonansi kognitif dapat terjadi pada unsur-unsur kognitif yang relevan atau yang ada hubungannya satu sama lain (Festinger, 1957)

Teori disonansi kognitif memiliki kaitan dalam penelitian ini yang dimana teori ini mampu menjelaskan bagaimana sikap skeptisme auditor jika terjadi disonansi kognitif dalam dirinya ketika mendeteksi kecurangan (Noviyanti, 2008). Tingkat kepercayaan (trust) auditor yang tinggi terhadap klien akan menurunkan tingkat skeptisme profesionalnya, demikian sebaliknya. Sedangkan pemberian penaksiran risiko kecurangan (fraud risk assessment) yang tinggi dari atasan auditor kepada auditor akan meningkatkan skeptisme profesionalnya, demikian sebaliknya. Disonansi kognitif terjadi apabila auditor mempunyai trust yang tinggi terhadap klien tetapi atasan auditor memberinya penaksiran risiko kecurangan yang tinggi. Teori disonansi kognitif juga membantu untuk menjelaskan apakah skeptisme profesional auditor terpengaruh atau tidak dengan fraud risk assessment (penaksiran risiko kecurangan) yang rendah yang ditetapkan oleh atasannya, padahal auditor sebenarnya mempunyai tingkat kepercayaan yang rendah terhadap klien. 
Kemampuan mendeteksi kecurangan berarti proses menemukan atau menentukan suatu tindakan ilegal yang dapat mengakibatkan salah saji dalam pelaporan keuangan yang dilakukan secara sengaja (Widiyanturi \& Pamudji, 2009). Pendeteksian kecurangan bukan merupakan tugas yang mudah dilaksanakan oleh auditor eksternal (selanjutnya disebut auditor). AICPA mengartikan bahwa kecurangan adalah tindakan yang dilakukan dengan sengaja dan mengakibatkan adanya salah saji material dalam laporan keuangan dimana laporan keuangan ini adalah subjek utama dalam audit.

Berbeda dengan penelitian terdahulu, yang dimana penelitian yang dilakukan oleh Ulfa (2015) tidak menggunakan variable moderasi dalam penelitiannya. Sehingga penelitian ini lebih diorientasikan untuk menguji kemampuan faktor kontinjensi, yaitu skeptisme profesional dalam memoderasi pengaruh audit training pada kemampuan deteksi kecurangan. Penelitian ini dilakukan pada auditor Kantor Akuntan Publik (KAP) Provinsi Bali. Riset ini diharapkan dapat memberi nilai tambah bagi pengembangan teori dan praktik audit, maupun perbaikan pengelolaan pendidikan akuntansi dan program pendidikan lanjutan (PPL) bagi auditor.

Dalam rangka memenuhi persyaratan sebagai seorang auditor yang profesional dan mampu mendeteksi terjadinya kecurangan maka auditor harus menjalani pelatihan yang cukup. Noviyani dan Bandi (2002) mengatakan bahwa pelatihan adalah suatu kegiatan yang bertujuan untuk meningkatkan kemampuan kerja peserta yang akhirnya akan menimbulkan perubahan perilaku aspek-aspek kognitif, ketrampilan dan sikap. Pramudyastuti (2014) menyatakan bahwa 
Cok Istri Mirah Pradnyaningrat Pemayun dan A.A.N.B. Dwirandra. Skeptisme...

pelatihan sebagai suatu latihan kecakapan, kemahiran, ketangkasan dalam melaksanakan tugasnya. Pelatihan bagi auditor tentu saja sangat penting karena dari pelatihan-pelatihan yang diikuti oleh auditor akan membantu mendeteksi suatu kecurangan.

Menurut hasil penelitian yang dilakukan oleh Ulfa (2015), pelatihan memiliki hubungan yang positif dan signifikan terhadap kemampuan mendeteksi kecurangan. Hal ini menunjukan bahwa seorang auditor yang lebih sering mengikuti pelatihan maka cenderung akan lebih mampu dalam mendeteksi kecurangan. Pelatihan akan menambah pengetahuan auditor mengenai lingkungan kerjanya, auditor lebih peka terhadap red flags kecurangan, sehingga auditor lebih mampu untuk mendeteksi kecurangan. Hal ini juga didukung dengan teori atribusi, dimana dikatakan keahlian profesional yang dimiliki melalui pelatihan, auditor harus dapat merumuskan pendapatnya dengan baik dan mampu mendeteksi kecurangan yang mungkin terjadi (Wahyudi, Nur, \& Saidi, 2014).

Hasil penelitian dari Dandi (2017) menunjukkan bahwa pelatihan mempunyai pengaruh dalam peningkatan keahlian dalam mendeteksi kecurangan. Hasil penelitian dari Rahayu \& Gudono (2016) menunjukkan bahwa pelatihan audit kecurangan berpengaruh positif terhadap kemampuan auditor dalam mendeteksi kecurangan. Dengan demikian, auditor dengan audit training dapat meningkatkan kemampuan auditor dalam mendeteksi kecurangan. Berdasarkan rerangka pemikiran teoritis dan logis serta hasil-hasil riset empiris di atas maka dapat dirumuskan hipotesis penelitian sebagai berikut

$\mathrm{H}_{1}$ : Audit training berpengaruh positifpada kemampuan deteksi kecurangan. 
Skeptisme profesional auditor adalah sikap yang mencakup pikiran yang selalu mempertanyakan dan melakukan evaluasi secara skeptis terhadap bukti audit, Skeptisme profesional auditor dapat dipengaruhi oleh beberapa faktor(Putri, Wirama, \& Sudana 2017). Menurut Hilmi (2011) mengatakan bahwa skeptisme professional auditor merupakan sikap (attitude) auditor dalam melakukan penuagasan audit dimana sikap ini mencakup pikiran yang selalu mempertanyakan dan melakukan evaluasi secara kritis terhadap bukti audit. Karena bukti audit dikumpulkan dan dinilai selama proses audit, maka skeptisme professional harus digunakan selama proses tersebut.

Sehingga dapat disimpulkan bahwa skeptisme profesional merupakan suatu sikap seimbang antara sikap curiga dan percaya terhadap perusahaan yang diaudit yang dimana harus dimiliki oleh auditor professional. Skeptisme profesional yang tinggi akan memberi dampak bagi performance auditor, sehingga memiliki motivasi untuk meningkatkan kemampuan dalam mendeteksi adanya kecurangan yang mungkin terjadi. Hadi dan Febria (2014) yang menyatakan bahwa pengaruh skeptisme profesional dapat dijelaskan dengan teori disonansi kognitif, teori ini membantu menjelaskan bagaimana auditor menggunakan skeptisme profesionalnya jika terjadi disonansi antara perilaku dan sikap.

Hasil penelitian Anggriyawan (2014) menemukan bahwa skeptisme profesional berpengaruh siginifikan terhadap kemampuan mendeteksi kecurangan. Pengaruh ini diindikasikan dengan semakin skeptis seorang auditor dalam mencari bukti, atau informasi atau melihat gejala-gejala kecurangan akan 
meningkatkan kemampuannya dalam mendeteksi akankah terjadinya kecurangan dalam perusahaan tersebut. Hasil yang sama pula disampaikan oleh Putri, Wirama, \& Sudana (2017) serta Hilmi (2011) yang menunjukan bahwa skeptisme professional auditor berpengaruh secara signifikan terhadap kemampuan auditor dalam mendeteksi kecurangan.

Berdasarkan paparan tersebut dikatakan bahwa skeptisme profesional berpengaruh positif pada kemampuan deteksi kecurangan. Sehinggga selanjutnya sangat mungkin memiliki kemampuan menguatkan pengaruh audit training pada kemampuan deteksi kecurangan.Berdasarkan hal tersebut maka dapat dirumuskan hipotesis penelitian sebagai berikut:

$\mathrm{H}_{2}$ : $\quad$ Skeptisme profesional menguatkan pengaruh positif audit trainingpada kemampuan deteksi kecurangan.

\section{METODE PENELITIAN}

Dalam penelitian ini jenis hubungannya adalah hubungan linier karena bertujuan untuk mengetahui pengaruh variabel bebas (X) dengan moderasi (M) terhadap variabel terikat $(\mathrm{Y})$. Objek dalam penelitian ini adalah kemampuan deteksi kecurangan, audit training, dan skeptisme professional auditor.

Masing-masing klasifikasi moderasi dapat diidentifikasi sebagaimana contoh berikut, jika $\mathrm{X}$ adalah variabel predictor, $\mathrm{Y}$ variabel tergantung dan $\mathrm{M}$ variabel moderasi maka persamaan regresi yang dapat dibentuk sebagai berikut:

$$
\begin{aligned}
& \hat{Y}_{1}=b_{0}+b_{1} X_{1} \ldots \ldots \ldots \ldots \ldots \ldots \ldots \ldots \ldots \ldots \ldots \ldots \\
& \hat{Y}_{1}=b_{0}+b_{1} X_{1}+b_{2} M_{1} \ldots \ldots \ldots \ldots \ldots \\
& \hat{Y}_{1}=b_{0}+b_{1} X_{1}+b_{2} M 1+b_{3} X_{1} * M_{1} \ldots
\end{aligned}
$$


Penelitian ini dilakukan pada Kantor Akuntan Publik (KAP) Provinsi Bali. Kantor Akuntan Publik (KAP) Provinsi Bali dipilih menjadi lokasi penelitian karena merupakan salah satu lembaga negara yang memiliki kewenangan berdasarkan perundang-undangan yang berlaku untuk melakukan pemeriksaan terhadap laporan berdasarkan fakta, keadaan yang ada, dan wajar. Daftar Kantor Akuntan Publik di Provinsi Bali dapat dilihat pada Tabel 1.

\section{Tabel 1.}

\section{Daftar Kantor Akuntan Publik di Provinsi Bali}

\begin{tabular}{|c|c|c|}
\hline No. & Nama Kantor Akuntan Publik & Alamat \\
\hline 1 & KAP I Wayan Ramantha & $\begin{array}{l}\text { Jl. Rampai No. IA Lt. 3, Denpasar, Bali. Telp: } \\
\text { (0361) } 263643\end{array}$ \\
\hline 2 & $\begin{array}{l}\text { KAP Johan Malonda Mustika \& } \\
\text { Rekan (cab) }\end{array}$ & $\begin{array}{l}\text { J1. Muding Indah I/5, Kerobokan Utara, Badung, } \\
\text { Bali. Telp: (0361) } 434884\end{array}$ \\
\hline 3 & KAP K. Gunarsa & $\begin{array}{l}\text { Jl. Tukad Banyusari Gg. II No. 5, Denpasar, Bali. } \\
\text { Telp: (0361) } 225580\end{array}$ \\
\hline 4 & KAP Drs. I Ketut Budiartha M. Si & $\begin{array}{l}\text { Perum Padang Pesona, Graha Adi A6, Jl. Gunung } \\
\text { Agung. Denpasar, Bali. Telp: (0361)8849168 }\end{array}$ \\
\hline 5 & KAP Drs. Wayan Sunasdyana & $\begin{array}{l}\text { Jl. Pura Demak I Gang I. B No. 8, Denpasar, Bali. } \\
\text { Telp: (0361) } 488660\end{array}$ \\
\hline 6 & $\begin{array}{l}\text { KAP Drs. Ketut Muliartha R. M. \& } \\
\text { Rekan }\end{array}$ & $\begin{array}{l}\text { J1. Drupadi No. 25, Denpasar, Bali. Telp: (0361) } \\
248110,265227\end{array}$ \\
\hline 7 & KAP Arnaya \& Darmayasa & $\begin{array}{l}\text { Jl. Cargo Indah III A, Perum Melang Hill No.1, } \\
\text { Ubung, Denpasar Utara, Denpasar, Bali. Telp: } \\
\text { (0361) } 4714308\end{array}$ \\
\hline 8 & KAP Budhananda Munidewi & $\begin{array}{l}\text { Jl. Tukad Irawadi No. } 18 \text { A, Lantai } 2 \& 3 \text {, } \\
\text { Kelurahan Panjer, Kecamatan Denpasar Selatan, } \\
\text { Bali. Telp: (0361) } 245644\end{array}$ \\
\hline 9 & $\begin{array}{l}\text { KAP Drs. Sri Marno Djogokarsono } \\
\text { \& Rekan }\end{array}$ & $\begin{array}{l}\text { Jl. Gunug Muria Blok VE No.4, Monang Maning, } \\
\text { Denpasar, Bali. Telp: (0361) 480033, 480032, } \\
482422\end{array}$ \\
\hline
\end{tabular}

Sumber: Institut Akuntan Publik Indonesia (IAPI), 2018

Populasi dalam penelitian ini adalah seluruh auditor di KAP Provinsi Bali.

Rincian auditor yang bekerja di KAP Provinsi Bali disajikan dalam Tabel 2. Teknik penentuan sampel yang digunakan dalam penelitian ini adalah teknik purposive sampling. 
Tabel 2.

Jumlah Auditor Pada Kantor Akuntan Publik di Provinsi Bali

\begin{tabular}{clc}
\hline No & \multicolumn{1}{c}{ Nama Kantor Akuntan Publik } & Jumlah Auditor \\
\hline 1 & KAP I Wayan Ramantha & 7 \\
2 & KAP Johan Malonda Mustika \& Rekan (cab) & 10 \\
3 & KAP K. Gunarsa & 13 \\
4 & KAP Drs. I Ketut Budiartha M. Si & 10 \\
5 & KAP Drs. Wayan Sunasdyana & 6 \\
6 & KAP Drs. Ketut Muliartha R. M. \& Rekan & 7 \\
7 & KAP Arnaya \& Darmayasa & 2 \\
8 & KAP Budhananda Munidewi & 8 \\
9 & KAp Drs. Sri Marno Djogokarsono \& Rekan & 17 \\
& $\quad$ TOTAL & 80 \\
\hline
\end{tabular}

Sumber: Data diolah, 2018

Kriteria penyampelan dalam penelitian ini adalah 1) Responden yang memiliki pengalaman kerja di KAP Provinsi Bali minimal 1 (satu) tahun, diasumsikan bahwa auditor yang telah bekerja selama 1 (satu) tahun sudah memiliki pengalaman dalam mengaudit. 2) Responden yang telah mengikuti pelatihan audit. 3) Responden yang tidak menolak mengisi kuesioner. 4) Responden yang mengisi kuesioner dengan lengkap

Berdasarkan kriteria diatas, maka dapat ditentukan jumlah sampel dalam penelitian ini adalah 40 auditor seperti pada Tabel 3.

Tabel 3.

Jumlah Sampel Pada Kantor Akuntan Publik di Provinsi Bali

\begin{tabular}{|c|c|c|c|c|c|c|c|}
\hline \multirow{2}{*}{ No. } & \multirow{2}{*}{ Nama Kantor Akuntan Publik } & \multirow{2}{*}{ Populasi } & \multicolumn{4}{|c|}{ Kriteria Sample } & \multirow{2}{*}{$\begin{array}{l}\text { Jumlah } \\
\text { Sampel }\end{array}$} \\
\hline & & & 1 & 2 & 3 & 4 & \\
\hline 1 & KAP I Wayan Ramantha & 7 & 7 & 4 & 4 & 4 & 4 \\
\hline 2 & KAP Johan Malonda Mustika \& Rekan (cab) & 10 & 10 & 5 & 5 & 5 & 5 \\
\hline 3 & KAP K. Gunarsa & 13 & 13 & 10 & 7 & 7 & 7 \\
\hline 4 & KAP Drs. I Ketut Budiartha M. Si & 10 & 10 & 10 & 10 & 9 & 9 \\
\hline 5 & KAP Drs. Wayan Sunasdyana & 6 & 6 & 6 & 6 & 4 & 4 \\
\hline 6 & KAP Drs. Ketut Muliartha R. M. \& Rekan & 7 & 7 & 7 & 7 & 7 & 7 \\
\hline 7 & KAP Arnaya \& Darmayasa & 2 & 2 & 2 & 2 & 1 & 1 \\
\hline 8 & KAP Budhananda Munidewi & 8 & 8 & 8 & 7 & 3 & 3 \\
\hline \multirow[t]{2}{*}{9} & KAP Drs. Sri Marno Djogokarsono \& Rekan & 17 & 15 & 10 & - & - & - \\
\hline & Total & 80 & & & & & 40 \\
\hline
\end{tabular}

Penelitian ini menggunakan teknik analysis regresi moderasi (moderated regression analysis) dengan menggunakan program Statistic Product and Service 
Solution (SPSS). Sebelum analisis regresi dilakukan, terlebih dahulu melakukan uji asumsi klasik, uji kelayakan model (Uji F), uji koefesien determinasi (Adj. $R^{2}$ ), dan terakhir uji hipotesis (Uji t).

Persamaan regresi yang dihasilkan dari model regresi moderasi dalam penelitian ini adalah:

$$
\mathrm{Y}=\mathrm{a}+\mathrm{b}_{1} \mathrm{X}_{1}+\mathrm{b}_{2} \mathrm{X}_{2}+\mathrm{b}_{3} \mathrm{X}_{1} \mathrm{X}_{2}+\mathrm{e}
$$

Keterangan :

$\mathrm{Y} \quad=$ Kemampuan Deteksi Kecurangan

a $\quad=$ Konstanta

$\mathrm{b}_{1}-\mathrm{b}_{3} \quad=$ Koefisien Regresi

$\mathrm{X}_{1} \quad=$ Audit Training

$\mathrm{X}_{2} \quad=$ Skeptisme Profesional

e $\quad=$ Standar error

\section{HASIL DAN PEMBAHASAN}

Jumlah responden berjenis kelamin laki-laki sebanyak 19 orang dengan persentase sebesar 47,50\% dan responden berjenis kelamin perempuan sebanyak 21 orang dengan persentase sebesar 52,50\%. Berdasarkan usia, responden yang berusia kurang dari 26 tahun sebanyak 29 orang dengan persentase sebesar 72,50\%, responden yang berusia 26-45 tahun sebanyak 7 orang dengan persentase sebesar $17,50 \%$, dan responden yang berusia lebih dari 45 tahun sebanyak 4 orang dengan persentase sebesar $10,00 \%$.

Berdasarkan jabatan, responden dengan jabatan sebagai partner sebanyak 1 orang dengan persentase sebesar $2,50 \%$, jabatan sebagai supervisor sebanyak 2 orang dengan persentase sebesar 5,00\%, jabatan sebagai senior auditor sebanyak 14 orang dengan persentase sebesar $35,00 \%$, dan jabatan sebagai junior auditor 
Cok Istri Mirah Pradnyaningrat Pemayun dan A.A.N.B. Dwirandra. Skeptisme...

sebanyak 23 orang dengan persentase sebesar 57,50\%. Berdasarkan tingkat pendidikan terakhir, responden dengan tingkat pendidikan Diploma sebanyak 1 orang dengan persentase sebesar $2,50 \%$, S1 sebanyak 35 orang dengan persentase sebesar $87,50 \%$, S2 sebanyak 3 orang dengan persentase sebesar 7,50\%, dan S3 sebanyak 1 orang dengan persentase sebesar $2,50 \%$. Serta berdasarkan masa kerjanya, responden yang bekerja lebih dari 1 tahun sebanyak 40 orang dengan persentase sebesar $100 \%$.

Analisis statistik deskriptif digunakan untuk memberikan informasi dari suatu data yang dilihat dari jumlah sampel, nilai minimum, nilai maksimum, nilai ratarata, dan standar deviasi dari masing-masing variabel penelitian. Hasil statistik deskriptif pada penelitian ini dapat dilihat pada Tabel 4.

Tabel 4.

Hasil Analisis Statistik Deskriptif

\begin{tabular}{lccccc}
\hline & $\mathrm{N}$ & Minimum & Maximum & Mean & Std. Deviation \\
\hline Audit Training $\left(\mathrm{X}_{1}\right)$ & 40 & 3.00 & 6.00 & 4.8665 & 0.53553 \\
Skeptisme Profesional $\left(\mathrm{X}_{2}\right)$ & 40 & 2.00 & 6.00 & 4.8548 & 0.62273 \\
Kemampuan Deteksi & 40 & 1.80 & 5.40 & 4.6325 & 0.66925 \\
Kecurangan (Y) & & & & & \\
Sumber: Data diolah, 2018 & & & &
\end{tabular}

Berdasarkan Tabel 4 dapat diketahui bahwa jumlah pengamatan (N) penelitian ini berjumlah 40. Rata-rata nilai persepsi auditor KAP di Bali terkait dengan audit training $I\left(\mathrm{X}_{1}\right)$, skeptisme profesional $\left(\mathrm{X}_{2}\right)$, dan kemampuan deteksi kecurangan (Y), masing-masing adalah sebesar 4,86; 4,85; 4,63 ini berarti bahwa dari ketiga variabel penelitian tersebut maka rata-rata tertinggi adalah terkait dengan audit training dan terendah adalah kemampuan deteksi kecurangan.

Dengan rata-rata persepsi auditor KAP di Bali seperti pada poin satu maka tidak satupun mencapai nilai maksimal sekala likert 6 poin. Sehingga, perlu 
ditelusuri pernyataan-pernyataan mana yang memperoleh skor terendah supaya dapat dicarikan solusinya.

Berdasarkan Tabel 5 dapat diinformasikan bahwa nilai signifikansi yang diperoleh sebesar 0,000 yang lebih kecil dari Alpha $(\alpha=0,05)$. Sehingga dapat dikatakan bahwa model regresi ini sudah tepat digunakan untuk diteliti.

Tabel 5.

Hasil Uji Kelayakan Model/goodness of fit (Uji F)

\begin{tabular}{llrrrrr}
\hline Model & & Sum of Squares & df & Mean Square & F & \multicolumn{1}{c}{ Sig. } \\
\hline 1 & Regression & 881.549 & 3 & 293.850 & 12.226 & $0.000^{\mathrm{b}}$ \\
& Residual & 865.226 & 36 & 24.034 & & \\
& Total & 1746.775 & 39 & & & \\
\hline
\end{tabular}

Sumber: Data diolah, 2018

Koefisien determinasi $\left(R^{2}\right)$ digunakan untuk mengukur kemampuan variabel bebas (Independen) menjelaskan variasi perubahan variabel terikat (dependen).

Tabel 6.

Hasil Analisis Koefisoen Determinasi $\left(\boldsymbol{R}^{2}\right)$

Model Summary

\begin{tabular}{|c|c|c|c|c|}
\hline Model & $\mathrm{R}$ & R Square & Adjusted R Square & $\begin{array}{l}\text { Std. Error of the } \\
\text { Estimate }\end{array}$ \\
\hline 1 & $.710^{\mathrm{a}}$ & .505 & .463 & 4.90245 \\
\hline
\end{tabular}
Sumber: Data diolah, 2018

Berdasarkan Tabel 6 dapat diketahui bahwa nilai $\mathrm{R}^{2}$ adalah 0,505 yang berarti bahwa variasi perubahan yang terjadi pada kemampuan deteksi kecurangan dapat dijelaskan oleh variabel audit training, dan skeptisme professional, interkasi audit training dan skeptisme profesional sebesar 50,5 persen, sedangkan 49,5 persen sisanya dijelaskan oleh faktor lain diluar model penelitian ini.

Penelitian ini menggunakan Moderated Regression Analysis (MRA) yang hasilnya tersaji pada tabel 7 . Berdasarkan Tabel 7 dapat diketahui dua hal yaitu persamaan MRA ekspetasian, dan hasil uji t. 
Tabel 7.

Hasil Uji Hipotesis

\begin{tabular}{|c|c|c|c|c|c|}
\hline \multirow[b]{2}{*}{ Model } & \multicolumn{2}{|c|}{$\begin{array}{l}\text { Unstandardized } \\
\text { Coefficients }\end{array}$} & \multicolumn{2}{|l|}{$\begin{array}{l}\text { Standardized } \\
\text { Coefficients }\end{array}$} & \multirow[b]{2}{*}{ Keterangan } \\
\hline & $\mathrm{B}$ & Std. Error & Beta & Sig. & \\
\hline (Constant) & 61.350 & 24.353 & & 0.016 & \\
\hline $\mathrm{X}_{1}$ & 3.691 & 1.074 & 1.762 & 0.002 & $\mathrm{H}_{1}$ diterima \\
\hline $\mathrm{X}_{2}$ & 3.155 & 0.881 & 1.772 & 0.001 & \\
\hline $\mathrm{X}_{1 \_} \mathrm{X}_{2}$ & 0.107 & 0.035 & 1.714 & 0.004 & $\mathrm{H}_{2}$ diterima \\
\hline \multicolumn{6}{|c|}{ a. Dependen Variable: y } \\
\hline
\end{tabular}

Berdasarkan tabel 7 dapat dibentuk model persamaan MRA ekspetasian sebagai berikut:

$$
Y=61,350+3,691 X_{1}+3.155 X_{2}+0,107 X_{1} X_{2}+24.353
$$

Persamaan MRA (2) tersebut dapat dijelaskan bahwa nilai konstanta sebesar 61,350. Hal ini berarti bahwa bila asumsikan nilai persepsi audit training $\left(\mathrm{X}_{1}\right)$, dan skeptisme professional $\left(\mathrm{X}_{2}\right)$, dan interaksi $\mathrm{X}_{1 \_} \mathrm{X}_{2}$ sama dengan nol maka responden (auditor KAP di Bali) mempersepsikan masih memiliki kemampuan deteksi kecurangan sebesar 61,350 satuan persepsi.

Nilai koefisien $\beta_{1}=3,691$ berarti bahwa dengan asumsi variabel $X_{2}$ dan interaksi $\mathrm{X}_{1 \_} \mathrm{X}_{2}$ konstan maka setiap peningkatan variabel audit training $\left(\mathrm{X}_{1}\right)$ sebesar satu satuan persepsi akan meningkatkan kemampuan deteksi kecurangan sebesar 3,691 satuan persepsi.

Nilai koefisien regresi $\beta_{2}=3.155$ berarti bahwa dengan asumsi variabel $X_{1}$ dan interaksi $\mathrm{X}_{1 \_} \mathrm{X}_{2}$ konstan maka setiap peningkatan variabel skeptisme profesional $\left(\mathrm{X}_{2}\right)$ sebesar satu satuan persepsi akan meningkatkan kemampuan deteksi kecurangan sebesar 3.155 satuan persepsi.

Nilai koedisien regresi $\beta_{3}=0,107$ berarti bahwa dengan asumsi variabel $X_{1}$ dan variabel $X_{2}$ konstan maka setiap peningkatan interaksi $X_{1 \_} X_{2}$ sebesar satu 
satuan persepsi akan meningkatkan kemampuan deteksi kecurangan sebesar 0,107 satuan persepsi.

Berdasarkan Tabel 7 dapat diketahui bahwa nilai sig. pengaruh $\mathrm{X}_{1}$ pada $\mathrm{Y}$ adalah 0,002 yang lebih kecil daripada alpha, maka hal tersebut berarti bahwa variabel audit training berpengaruh positif pada kemampuan deteksi kecurangan. Hasil penelitian ini menerima hipotesis $\mathrm{H}_{1}$ yang mengatakan bahwa audit training berpengaruh positif pada kemampuan deteksi kecurnagan.

Berdasarkan Tabel 7 dapat diketahui bahwa nilai sig. interaksi $\mathrm{X}_{1 \_} \mathrm{X}_{2}$ adalah 0,004 yang lebih kecil daripada alpha, maka hal tersebut berarti bahwa skeptisme profesional menguatkan pengaruh positif audit training pada kemampuan deteksi kecurangan.

Tambahan informasi uji parsial $\mathrm{X}_{2}$, seperti yang tersaji pada Tabel 7 diketahui bahwa skeptisme profesional memiliki nilai sig. sebesar 0,001 lebih kecil dari alpha $5 \%(0,05)$ yang berarti bahwa $\mathrm{X}_{2}$ memiliki pengaruh terhadap kemampuan deteksi kecurangan. Sehingga menurut Solimun (2010) berdasarkan nilai sig. variabel $X_{2}$ dan interaksi $X_{1 \_} X_{2}$ (pada poin 2) dikarenakan keduanya memiliki nilai yang signifikan maka dapat di katakana bahwa skeptisme profesional merupakan quasi moderasi (Pemoderasi semu).

Hasil penelitian ini menunjukan bahwa audit training berpengaruh positif pada kemampuan deteksi kecurangan. Dengan demikian dapat diketahui bahwa audit training memiliki pengaruh yang searah dengan kemampuan deteksi kecurangan. Dimana dengan semakin tingginya audit training yang dilakukan 
oleh auditor maka kemampuan auditor dalam mendeteksi kecurangan akan semakin meningkat pula.

Berbeda dengan penelitian yang disampaikan oleh Sanjaya (2018) mengatakan bahwa pelatihan tidak berpengaruh secara siginifikan terhadap kemampuan deteksi kecurangan. Yang dimana dijelaskan bahwa pelatihan auditor memang merupakan hal yang sangat diperlukan bagi auditor untuk menunjang kinerja dibidang audit, dengan mengikuti pelatihan audit secara terus menerus tidak menjamin auditor memiliki tanggungjawab dalam mendeteksi kecurangan. Hal tersebut karena setiap pelatihan yang diikuti oleh auditor akan memiliki dampak yang berbeda bagi masing-masing auditor, meskipun pelatihan yang diikuti sama.

Namun, hasil penelitian ini mendukung penelitian sebelumnya yang mengatakan bahwa pelatihan memiliki hubungan yang positif dan signifikan terhadap kemampuan mendeteksi kecurangan. Hal ini menunjukan bahwa seorang auditor yang memiliki pelatihan cenderung akan lebih mampu dalam mendeteksi kecurangan. Pelatihan akan menambah pengetahuan auditor mengenai lingkungan kerjanya, dan auditor akan lebih peka terhadap red flags kecurangan, sehingga auditor lebih mampu untuk mendeteksi kecurangan (Ulfa, 2015). Pelatihan merupakan upaya untuk mentransfer keterampilan dan pengetahuan kepada para peserta pelatihan dalam rangka meningkatkan kemampuan auditor dalam mendeteksi suatu kecurangan dalam perusahaan yang diaudit (Dandi, 2017). Maka dengan mengikuti pelatihan audit, auditor akan memiliki kemampuan dan pengetahuan yang lebih untuk dapat diimplementasikan atau digunakan saat 
melakukan audit pada perusahaan yang diaudit, sehingga auditor akan lebih mudah dan lebih mampu dalam mendeteksi kecurangan yang ada.

Hasil penelitian ini menunjukan bahwa skeptisme profesional mampu menguatkan pengaruh positif audit training pada kemampuan deteksi kecurangan.Fajarwati (2014) menyatakan baha skeptisme profesional auditor merupakan sikap yang dimiliki auditor yang selalu mempertanyakan dan meragukan bukti audit hal tersbut dapat diartikan bahwa skeptisme profesional menjadi salah satu faktor dalam menentukan kemahiran profesional seorang auditor. Pramudyastusi (2014) menyebutkan bahwa salah satu penyebab ketidakmampuan auditor dalam mendeteksi kecurangan dalam laporan keuangan itu adalah minimnya sikap skeptis yang dimiliki oleh auditor. Oleh sebab itu, dengan sikap skeptis yang meningkat yang dimiliki oleh auditor maka akan mempermudah auditor dalam mendeteksi kecurangan. Hal ini didukung juga dengan penelitian Noviyanti (2008) yang menyatakan bahwa kurangnya skeptisme profesional yang dimiliki oleh seorang auditor menyebabkan turunnya kemampuan auditor dalam mendeteksi kecurangan yang mungkin terjadi.

Jadi apabila seorang auditor menginginkan kemampuannya dalam mendeteksi kecurangan lebih baik maka selain mengikuti pelatihan audit, auditor juga perlu memiliki sikap skeptisme perofesional yang dimana akan menguatkan pengaruh audit training pada kemampuan auditor dalam mendeteksi kecurangan.

Penelitian yang dilakukan dapat memberikan kontribusi mengenai pengaruh audit training pada kemampuan deteksi kecurangan dengan skeptisme profesional sebagai variabel pemoderasi. Berdasarkan hasil uji dalam penelitian ini dapat 
diketahui bahwa kemampuan deteksi kecurangan tidak hanya dipengaruhi secara parsial oleh audit training melainkan adanya faktor kontijensi berupa variabel skeptisme profesional yang mampu lebih meningkatkan pengaruh audit training pada kemampuan deteksi kecurangan. Lebih lanjut juga diketahui bahwa tipe pemoderasi dari variabel skeptisme profesional berdasarkan hasil penelitian dan mengacu pada tipe pemoderasi Solimun 2010, maka variabel skeptisme profesional adalah quasi moderasi (pemoderasi semu).

Berdasarkan hasil penelitian maka perlu diperhatikan bahwa dalam meningkatkan kemampuan deteksi kecurangan auditor KAP manajemen KAP tidak hanya mempertimbangkan frekuensi dan intensitas audit training melainkan juga mengembangkan atau melaksanakan berbagai upaya untuk meningkatkan skeptisme profesioanl yang inheren dialam auditor KAP tersebut.

\section{SIMPULAN}

Berdasarkan hasil analisis data dan pembahasan yang telah diuraikan diatas, maka dapat ditarik kesimpulan bahwa variabel audit training berpengaruh positif pada kemampuan deteksi kecurngan. Hal ini berarti bahwa semakin sering pelatihan audit (audit training) yang diikuti oleh auditor maka kemampuan deteksi kecurangan yang dimiliki auditor akan semakin meningkat.

Variabel skeptisme profesional sebagai mediator audit training pada kemampuan deteksi kecurangan. Hal ini berarti bahwa skeptisme profesional memperkuat pengaruh positif audit training pada kemampuan deteksi 
kecurangan. Apabila auditor sering mengikuti audit training ditambah memiliki sikap skeptisme profesional maka auditor akan lebih mampu dalam mendeteksi adanya kecurangan.

Penelitian ini diharapkan mampu memberikan kontribusi bagi auditor pada Kantor Akuntan Publik (KAP) di Provinsi Bali. Berdasarkan skor penilaian responden tidak ada yang mencapai skala 6 , yang berarti bahwa masih kurangnya auditor pada KAP Provinsi Bali mengikuti audit training, kurang memiliki sikap skeptisme profesional serta kurang dalam mampu dalam mendeteksi kecurangan. Sehingga alangkah baiknya auditor pada KAP Provinsi Bali lebih sering mengikuti audit training dengan baik serta memupuk sikap skeptisme profesional lebih mendalam agar tugas yang dijalankan dalam mengaudit dapat menghasilkan hasil yang akurat sertah jauh dari adanya kegagalan dalam mendeteksi kecurangan.

Peneliti selanjutnya dapat memperluas area penelitian, tidak hanya pada Kantor Akuntan Publik saja tetapi dapat memperluas area penelitian di Kantor BPK/BPKP, sehingga hasilnya lebih dapat digeneralisasi.Penelliti selanjutnya dapat melakukan uji moderasi dengan menggunakan varibel kontingensi lainnya, seperti tekanan ketaatan, independensi, audit premature, dan wistheblowing.Penelitian selanjutnya dapat melakukan uji mediasi dengan menggunakan variabel yang tercantum pada point (2) atau dengan variabel lain yaitu supervise audit, kompensasi audit dan lain sebagainya. 


\section{REFERENSI}

Anggriawan, E. F. (2014). Pengaruh Pengalaman Kerja, Skeptisme Profesional Dan Tekanan Waktu Terhadap Kemampuan Auditor Dalam Mendeteksi Fraud (Studi Empiris Pada Kantor Akuntan Publik Di Diy). Jurnal Nominal, 3(2), 101-116.

Bulchia. (2008). Analisis Pengaruh Pengalaman Dan Pelatihan Auditor Terhadap Pengetahuan Auditor Dalam Mendeteksi Kecurangan. E-Journal Warmadewa, 5(2), hal.123-135.

Dandi, V. (2017). Pengaruh Beban Kerja, Pelatihan Dan Tekanan Waktu Terhadap Kemampuan Auditor Dalam Mendeteksi Kecurangan (Studi Empiris BPK RI Perwakilan Provinsi Riau). Jom FEKON, 4(1), hal.302-322.

Fajarwati, sutrisno \& D. (2014). Pengaruh Pengalaman,Keahlian, Situasi Audit, Etika, Dan Gender Terhadap Ketepatan Pemberian Opini Auditor Melalui Skeptisme Profesional Auditor ( Studi kasus pada KAP di Bekasi ), EJournal Warmadewa ,5(2), hal.1-15.

Festinger, L. (1993). La Teoria De La Disonancia Cognoscitiva. Psychology Journals, 5(1), pp.201-206.

Govindarajan, V.(1986). Impact of Participation in The Budgetary Process on Managerial Attitudes and Performance: Universalistic and Contingency Perspective. Decision Sciences 17:496-516.

Hadi, S. (2014). Pengaruh Independence In Attitude Dan Pengalaman Terhadap Skeptisisme Profesional Auditor. Jurnal Ekonomi Dan Bisnis Islam, 8(2), hal.218-234.

Haryanti, C. S. (2013). Pengaruh Pengalaman Dan Pelatihan Auditor Terhadap Struktur Pengetahuan Tentang Kekeliruan Auditor. Jurnal Ilmiah Dinamika Ekonomi Dan Bisnis, 1(1), hal.30-41.

Hilmi, F. (2011). Pengaruh Pengalaman, Pelatihan Dan Skeptisme Profesional Auditor Terhadap Pendeteksian Kecurangan ( Studi Empiris Pada Kantor Akuntan Publik di Wilayah Jakarta ). Jurnal Ekonomi Dan Bisnis, 3(5), hal.11-15.

Institut Akuntan Publik Indoneasia. (2018). Standar Audit ('SA") 240 tentang Tanggung Jawab Auditor Terkait Dengan Kecurangan Dalam Suatu Audit Atas Laporan Keuangan.

Institut Akuntan Publik Indonesia (IAPI). (2018). Diunduh dari website: https://iapi.or.id/ 
Maulana, Agus. (2014). Kecurangan (Fraud) Dalam Akuntansi Dan Etika Profesi AKuntansi. Diunduh dari website: http://waterdoorblanco.blogspot.co.id/2014/11/kecurangan-fraud-dalam-akuntansi-dan.html.

Murray, Dennis. (1990). The Performance Effects of Participative Budgeting: An Integration of Intervening and Moderating Variables. Behavior Research In Accounting, 4(2), pp.104-121.

Nasution, H. (2013). Pengaruh Beban Kerja, Pengalaman Audit Dan Tipe Keperibadian Terhadap Skeptisme Profesional Dan Kemampuan Auditor Dalam Mendeteksi Kecurangan. Climate Change 2013 - The Physical Science Basis Journal, 53(9), hal.1-30.

Noviyanti, S. (2008). Skeptisme Profesional Auditor Dalam Mendeteksi Kecurangan. Jurnal Akuntansi Dan Keuangan Indonesia, 5(I), hal.102-125.

Pambudi, T. (2016). Faktor-Faktor Yang Mempengaruhi Kemampuan Auditor Dalam Mendeteksi Kecurangan: Studi Empiris pada Auditor Internal di Perguruan Tinggi BLU dan BH Jawa Tengah dan Derah Istimewa Yogyakarta. Jurnal Ilmiah Dinamika Ekonomi dan Bisnis, 6(2), hal.456-570.

Putri, K. M. D., Wirama, D. G., \& Sudana, I. P. (2017). Pengaruh Fraud Audit Training, Skeptisisme Profesional, Dan Audit Tenure Pada Kemampuan Auditor Dalam Mendeteksi Kecurangan. E-Jurnal Ekonomi Dan Bisnis Universitas Udayana, 11(6), hal.3795-3822.

Pramudyastuti, O. L. (2014). Pengaruh Skeptisisme Profesional, Pelatihan Audit Kecurangan, dan Independensi Terhadap Kemampuan Auditor Dalam Mendeteksi Kecurangan (Studi di Inspektorat Kabupaten Slema). Tesis. Fakultas Ekonomika Dan Bisnis Universitas Gadjah Mada. Yogyakarta.

Rahayu, S., \& Gudono. (2016). Faktor-Faktor yang Mempengaruhi Kemampuan Auditor dalam Pendeteksian Kecurangan: Sebuah Riset Campuran dengan Pendekatan Sekuensial Eksplanatif Full Paper Siti Rahayu Politeknik Negeri Pontianak Gudono. Simposium Nasional Akuntansi,XIX, Lampung, 131September 2016.

Sanjaya, A. (2018). Pengaruh Skeptisisme Profesional, Independensi, Kompetensi, Pelatihan Auditor, Dan Resiko Audit Terhadap Tanggung Jawab Auditor Dalam Mendeteksi Kecurangan. Jurnal Akuntansi Bisnis, 15(30), hal.144-158.

Solimun. (2010). Analisis Multivariat Pemodelan Struktural Metode Partial Least Squer-PLS. CV Citra: Malang.

Tunggal, A. W. (2016). Aspek-Aspek Audit Kecurangan Edisi 2016. Jakarta: 
Havarindo.

Ulfa, N. (2015). Pengaruh Pengalaman, Beban Kerja, Dan Pelatihan Terhadap Skeptisme Dan Kemampuan Auditor Dalam Mendeteksi Kecurangan (Studi Empiris Pada Auditor di BPKP Perwakilan Provinsi Riau). Jom FEKON, 2(1), hal.1-16.

Wahyudi, D. P., Nur, E., \& Saidi, J. (2014). Faktor yang mempengaruhi pemberian opini audit dalam laporan keuangan melalui pertimbangan materialitas dan skeptisme profesional auditor. Igarss 2014, (1), hal.1-5.

Widiyanturi, M. (FE U., \& Pamudji, S). (2009). Pengaruh Kompetensi, Independensi, Dan Profesionalisme Terhadap Kemampuan Auditor Dalam Mendeteksi Kecurangan. Jurnal Fakultas Ekonomi Universitas Pandjadjaran (UNPAD) Bandung, 5(2), hal.52-73.

Wiguna, F. (2015). Pengaruh Skeptisisme Profesional dan Independensi Auditor terhadap Pendeteksian Kecurangan (Survei Pada Auditor KAP di Malang). Jurnal Ekonomi Dan Bisnis, 2(1), hal.453-461. 